\title{
TURISMO E REPERCUSSÕES NO ESPAÇO GEOGRÁFICO
}

\author{
OIga Tulik*
}

\begin{abstract}
RESUMO: A prática do turismo concorre para introduzir mudanças no espaço geográfico desencadeando uma grande variedade de problemas, propostas e alternativas que, de um modo geral, aparecem vinculadas ao meio-ambiente. Esta análise revela repercussōes do turismo no espaço geográfico, incluindo desde questōes ambientais amplas, até o exemplo particularizado de comunidades de pescadores artesanais que se transformaram em núcleos de periferia urbana.
\end{abstract}

UNITERMOS: Geografia: turismo; meio-ambiente. Turismo: geografia.

ABSTRACT: The practice of tourism comes together to introduce changes in the geographic space by unchaining a great variety of problems, proposals and alternatives that, in a common way, show up linked to the environment. This analysis unveils echoes of tourism in the geographic space, rar.ging from broad environmental matiers to the peculiar example of rough fishermen communities that became into outskirts nuclei.

KEY WORDS: Geography: tourism; environment. Tourism: geography.

\section{GEOGRAFIA, TURISMO E MEIO-AMBIENTE}

Ao contrário de outros especialistas cuja preocupação com o turismo está centralizada em aspectos específicos, como a natureza da oferta técnica, a estrutura institucional e operacional e as motivaçōes, o geógrafo concentra seu interesse na expressão espacial deste fenômeno.

A prática do turismo ocorre num espaço concreto e dinâmico, podendo provocar alteraçōes no mesmo. Do conflito à harmonia, dificilmente alcançada, existe uma grande variedade de problemas,

(*) Professor Assistente Doutor no Curso de Turismo da ECA/USP. Geógrafo do Museu Paulista da Universidade de São Paulo.

End. para corresp.: Rua Conde de lrajá, 184, apto. 224 - CEP O4118 - São Paulo - SP .

Brasil. 
propostas e alternativas que, de um modo geral, aparecem vinculadas ao meio-ambiente. Todavia, a questão ambiental, transformada em modismo nas últimas décadas, tem suscitado mais polêmicas e manifestações, muitas vezes de cunho político e ideológico, do que análise e reflexão. É indiscutível, porém, que existe uma relação muito estreita entre turismo e meio-ambiente, que pode ser percebida no decorrer de todo o processo turístico, desde as razões da saída (entre as quais a qualidade do clima, os atrativos do sítio e a originalidade de certos atributos) até a transformação do núcleo receptor.

Para melhor entender as relações entre turismo ${ }^{1}$ e meio-ambien$\mathrm{te}^{2}$, convém conceituar cada um destes termos, o que escapa aos objetivos desta análise. Todavia, deve-se considerar que o conceito de meio-ambiente, hoje, não inclui apenas terra, água, ar, flora e fauna mas engloba, também, “o povo, suas criações e as condições sociais, econômicas e culturais que afetam suas vidas"3. Sob esta 6́tica, a questão ambiental engloba o próprio homem, com todas as suas manifestações, transformando-o de simples observador em participante desse complexo jogo de interações que repercutem no espaço gea gráfico.

\section{LITERATURA ESPECÍFICA DIANTE DA QUESTẢO DOS IMPACTOS}

No que se refere à área específica da Geografia do Turismo, as pesquisas até agora realizadas não correspondem à preocupação manifestada pelos especialistas e, nem tampouco, à importância que é atribuída ao tema. De um modo geral, o volume de trabalhos é reduzido, mesmo nos Estados Unidos, onde a preocupação com o meioambiente não apenas é antiga como também persistente. Além disso, poucas obras tratam unicamente das relações entre turismo e meioambiente como ocorre, por exemplo, com "Tourism: economic, physical and social impacts"4 e "Le tourisme face à l'environnement"5. $\mathrm{Na}$ maioria das vezes, o que se observa são estudos esparsos e isolados, abordando apenas um componente ou uma região.

Analisando a bibliografia geográfica referente aos impactos ambientais, Mathieson e Wall registram dificuldades conceituais e mo todológicas a propósito do estudo da recreação como um todo. Conforme esses autores, as pesquisas abrangem assuntos desiguais $e$ estão particularmente disseminadas em estudos do solo e da qualidade da água e do ar. Observam ainda que, muitas vezes, a ênfase regional dificulta comparar efeitos ecológicos, o que é agravado pelo 64 fato de que a maioria das pesquisas apenas registra danos posteriores. Além disso, observam que as investigações sobre impactos do turismo revelam: dificuldades em isolar mudanças induzidas apenas pelo turismo, falta de informações a respeito das condições existentes antes do advento do turismo, desconhecimento quanto ao número, tipos e níveis de tolerância da flora e da fauna, e concentração em áreas específicas, como praias e montanhas. ${ }^{6}$

No caso brasileiro, a situação é ainda mais grave, pois a preocupação com o meio-ambiente não alcançou a repercussão que o turismo possa vir a ter sobre o espaço geográfico. Algumas pesquisas apenas insinuam o turismo quando se referem a outras questōes, mencionando certos componentes do meio-ambiente como atrativos ${ }^{7}$, enquanto outras registram alterações ambientais derivadas desse fenômeno.

Entretanto, isto é pouco para um país que desperta para o chamado "turismo ecológico", que vem sendo amplamente divulgado através da imprensa e de folhetos de propaganda, servindo como "chamariz de venda" e que começa a desenvolver outras atividades turísticas e de lazer, com base nas condições ambientais.

Percebe-se, através da análise de evidências de efeitos do turismo documentados nas pesquisas, que a ação antrópica provoca impactos em todos os aspectos do meio-ambiente. No que se refere à literatura de Geografia do Turismo, os impactos registrados abrangem aspectos físicos, vida animal e ambientes criados pelo homem. ${ }^{8}$

O impacto nos aspectos físicos pode ser observado em componentes variados e em diferentes escalas. Entre estes efeitos, merecem ser mencionadas, pela freqüência com que aparecem, a destruição e a remoção da cobertura vegetal, em virtude da proliferação de loteamentos, construção de alojamentos e equipamentos, tráfego de pedestres ou de veículos, ação do fogo e coleta de espécies; o comprometimento da qualidade da água pela poluição de esgotos e combustíveis das embarcaçôes (aos quais se juntam outros agentes poluidores) que prejudicam a flora e a fauna e, também, as atividades de recreação e lazer (natação, pesca esportiva, iatismo); a poluição do ar como conseqüência do aumento do tráfego de veículos; e, finalmente, atos de vandalismo em grutas e cavernas que incluem inscriçōes e a retirada de pinturas rupestres, artefatos arqueológicos, minerais, rochas e fósseis.

A interferência do turismo na vida animal ocorre através da práica de atividades turísticas como a caça e a pesca por divertimento. No caso da vida selvagem, Mathieson e Wall observam que os estudos estão centralizados em grandes mamíferos e aves, não revelando 
efeitos em pequenos mamíferos e insetos. Revelam, ainda, que os trabalhos enfatizam impactos de alto grau em parques e reservas e que, além disso, existe falta de base ecológica nas pesquisas realizadas, como, por exemplo, no que se refere à abordagem das migraçōes, ao comportamento dos animais e à adaptação a mudanças do "habitat". Conforme esses autores, os impactos indiretos na vida selvagem aparecem relacionados à resistência animal, à presença de turistas e à sua adaptabilidade; os impactos diretos, todavia, têm correspondência com os "souvenirs", principalmente quando praticados por coletores profissionais. 9

Os impactos no ambiente criado pelo homem ocorrem porque os atrativos são insuficientes para satisfazer o turista. Sendo assim, torna-se preciso uma complementação de serviços, tais como facilidades turísticas e infra-estrutura de apoio para atender às necessidades do turista ${ }^{i}$. Esses serviços constituem os elementos da oferta compreendidos nas estruturas e processos do desenvolvimento turístico que podem ser agrupados em cinco amplos setores: atrações, transportes, facilidades de apoio, acomodações e infra-estrutura ${ }^{11}$. Neste caso, os efeitos do turismo têm sido observados em três grandes tipos de desenvolvimento turístico que englobam o.crescimento e mudanças nos recursos turísticos, o desenvolvimento de hotéis nas cidades e o desenvolvimento de segundas-residências no meio rural ${ }^{12}$ Miossec, ao determinar a evolução e a estrutura de regiōes turísticas, no tempo e no espaço, registra alguns destes efeitos em sua síntese da dinâmica do espaço turístico ${ }^{13}$.

Entre os principais impactos ocasionados pelo desenvolvimento e mudanças nos recursos turísticos, merecem destaque, pela freqüência com que são mencionados na bibliografia específica, a poluição arquitetônica, a franja de edifícios nas praias, o congestionamento do tráfego, a sobrecarga da infra-estrutura e a segregação dos residentes locais ${ }^{14}$. Por outro lado, um sério problema desencadeado pola proliferação de residências-secundárias no meio rural 15 é o parcelamento acentuado da estrutura fundiária que, além dos efeitos no patrimônio natural, concorre indiretamente para o êxodo rural. Da mesma forma, o desenvolvimento da rede hoteleira nas cidades encontra opositores porque introduz elementos que contribuem para deteriorar a qualidade de vida dos habitantes 16

As repercussōes do turismo no espaço geográfico são evidentes em muitas áreas turísticas em razão de conflitos de interesses. Isto ocorre, geralmente, porque nem sempre os interesses do turismo coincidem com os das atividades econômicas do núcleo receptor. Como muitos destes conflitos foram observados no meio rural, surgi66 rarn várias adaptações entre as quais estão os hotéis-fazenda, os "campings" educativos, a exploração de produtos agrícolas como atrativos turísticos (como, por exemplo, os eventos apoiados num produto regional) e a promoção de uma grande variedade de atividades recreativas vinculadas ao meio rural.

Muitas vezes, o desenvolvimento turístico ocorre em áreas particularmente frágeis, como é o caso das regiōes litorâneas, das pequenas ilhas oceânicas e das montanhas, provocando impactos que repercutem no espaço geográfico.

A moda dos banhos de mar e da exposiçẫo ao sol ocasionou o desenvolvimento do turismo litorâneo que tem provocado perturbações sem precedentes ${ }^{17}$ e, em muitos casos, irreversíveis nos ecossistemas $\operatorname{costeiros}^{18}$. Estes efeitos negativos que, na maioria das vezes, refletem planejamentos falhos ou inexistentes, incluem, inevitavelmente, a poluição da água e a eliminação dos "habitats" da fauna e da flora. O mesmo ocorre nos ecossistemas das ilhas oceânicas onde o conflito sé manifesta em virtude do atendimento das necessidades do turista. Por exemplo, a faita de água potável em algumas destas ilhas tem exigido a utilização de água salgada, que retorna ao mar, sem qualquer tratamento, agredindo a vida marinha ${ }^{19}$ e prejudicando a balneabilidade das praias.

$\mathrm{O}$ turismo chega a ser apontado como o fator que mais contribui para a transformação de algumas localidades de montanha 20 . Neste caso, as relações negativas têm ocorrido em razão da construção de acomodações, estradas, teleféricos, pistas para esquis, destruição da vegetação e comprometimento da estabilidade das vertentes.

\section{TURISMO: MALÉFICO OU BENÉFICO?}

Representando apenas uma parcela do conjunto de atividades humanas que repercutem no espaço geográfico, o turismo, entretanto, não pode ser responsabilizado por toda a carga de impactos ambientais. Todavia, em virtude da velocidade e da intensidade com que atua no espaço, a par com os efeitos induzidos que atingem a economia, a cultura e a sociedade dos núcleos receptores, o turismo te $m$ suscitado reaçōes antagônicas. Assim, enquanto para alguns o turismo é nocivo, para outros ele é benéfico.

$\mathrm{O}$ aspecto autodestrutivo do turismo ${ }^{21}$ tem sido muito destacado na questão dos impactos. Para aqueles que o consideram nocivo ao meio-ambiente, sua ação se manifesta, sobretudo, pela agressão. 
Muitos destacam a ocupação predatória, não-planificada, subordinada aos interesses do máximo proveito. Outros ressaltam o problema dos loteamentos em vertentes expostas à erosão, da destruição da coberiura vegetal e da ocupação de áreas impróprias como é o caso das restingas, bacias de captação de águas fluviais e cabeceiras em anfiteatro, ocasionando o desaparecimento dos lençóis freáticos e das fontes.

O turismo é, ainda, responsabilizado pela poluiçăo em todas as suas formas, inclusive a arquitetônica, pois favorece a proliferação de estilos em desacordo com o material, com o nível sócio-econômico e com as condiçôes geográficas do núcleo receptor. Além disso, tem sido considerado como uma ameaça à identidade cultural das comunidades hospedeiras diante da comercialização e afluência de valores alienígenas. 22

A situação se complica quando a infra-estrutura não corresponde à demanda, o que contribui para reduzir a qualidade de vida dos residentes que, muitas vezes, pagam por serviços que não utilizam. $\mathrm{Pa}-$ ra a grande maioria, o turismo é nocivo ao meio-ambiente porque concorre decisivamente, e de modo nefasto, para mudanças sociais, econômicas e ambientais. ${ }^{23}$

Para outros, entretanto, o turismo se revela benéfico ao meioambiente porque, através de sua presença econômica, pode contribuir para a conservação e preservação de monumentos históricos, áreas naturais e sítios arqueologicos. Além disso, o turismo tem interesse em manter a qualidade do meio-ambiente e deve promover a sua conservação, não apenas porque historicamente está ligado a ele, mas também porque sua existência depende da natureza. 24

Conforme seus defensores, o turismo descobriu e tornou acessiveis regiões específicas e certos aspectos naturais (como é o caso do Pantanal e do "turismo ecologico"), e contribuiu para a permanência de muitas manifestações culturais. Além disso, proporciona incentivos e meios econômicos para a conservação ambiental. ${ }^{25}$

Muitos admitem a possibilidade de uma convivência harmoniosa entre o turismo e o meio-ambiente, principalmente em áreas desenvolvidas. Esta coexistência pacífica, conforme Mathieson e Wall, pode ser desenvolvida através da conservação com a presença do turista. Para esses autores, tal alternativa vem ocorrendo de quatro modos:

a) estímulo à existência e à reabilitação de sítios históricos, construções e monumentos, transformando o passado em recurso re creacional b) revitalização de atividades tradicionais de áreas em declínio, redescoberta de sítios com propriedades específicas e de cidades históricas, estimulando a transformação de antigas habitações em acomodações turísticas, mantendo a estrutura e as características tradicionais;

c) estímulo à conservação de recursos naturais (como, por exemplo, os parques), através dos recursos econômicos que proporciona e das pressões políticas e sociais;

d) responsabilidade de ter introduzido a administração e planos de desenvolvimento, estimulando a conservação de paisagens e de sítios históricos e arqueológicos, contribuindo, assim, para a conservação do meio-ambiente. ${ }^{26}$

\section{IMPACTO EM DUAS COMUNIDADES CAIÇARAS: Praia do Góis e Prainha Branca}

Geralmente espontânea e complexa, a relação do turista com o núcleo receptor concorre para introduzir mudanças socioculturais e econômicas, que repercutem no espaço geografico. A velocidade e a intensidade destas transformações dependem de uma série de fatores, entre os quais está o grau de isolamento das comunidades hospedeiras. Neste caso, incluem-se as pequenas comunidades de pescadores artesanais que passam a ser procuradas para fins de turismo e lazer. A propósito, é significativo o exemplo dos núcleos da Praia do Góis e da Prainha Branca, localizados na ilha de Santo Amaro, que constitui parte integrante da Baixada Santista, na porção central da fachada atlântica do Estado de São Paulo. 27

Núcleos populacionais espontâneos e modernos, embora localizados numa área de colonização antiga, Praia do Góis e Prainha Branca formaram-se no início deste século, quando ali se estabeleceram caiçaras, lavradores e pescadores que imprimiram à paisagem muitos dos traços ainda hoje perceptiveis. Destes sinais, verdadeiros legados da tradição cultural, muitos desapareceram, por razōes diversas, enquanto outros permanecem constituindo atrativos que estimulam a procura destas pequenas praias para fins de turismo e de lazer. 28

Um dos principais fatores que explica a permanência de muitos dos característicos tradicionais observados é, sem dúvida, o relativo isolamento de que estes núcleos desfrutam em razão das dificuldades de acesso. Esse importante fator, decorrente das condições geográfi- 
cas dos sítios onde se instalaram essas comunidades, tem contribuído para atenuar as influências da proximidade urbana.

Na Praia do Góis, a única via terrestre existente é um estreito caminho que, seguindo pela costeira, dá acesso até a Praia da Pouca Farinha e, somente através desta praia, torna-se possível atingir a cidade do Guarujá. Praia do Góis está, assim, praticamente isolada da sede do município a que pertence, o que lhe traz uma série de desvantagens. Por outro lado, está voltada para o estuário santista e os seus moradores podem tirar proveito dos benefícios oferecidos pelo bairro da Ponta da Praia, facilmente alcançado por meio de catraias ou "chatinhas". Esse fato contribuiu para que se estabelecesse entre esse núcleo e Santos uma relação muito estreita. Assim, é em Santos, principalmente no bairro da Ponta da Praia, que os habitantes do Góis estudam, trabalham, fazem compras e cumprem seus deveres religiosos e sociais. Além disso, foi ainda graças à posição que o núcleo ocupa na ilha de Santo Amaro que, depois de 1962, se intensificou a vinda de forasteiros de fim de semana, o que concorreu para que muitos dos moradores pudessem exercer atividades no próprio local e, conseqüentemente, melhorou o padrão de vida da populaçãe do núcleo.

O núcleo da Prainha Branca está situado a trinta quilômetros da sede municipal (Guarujá) e a quase rês quilômetros de distância da rodovia Guarujá-Bertioga, à qual está ligado por um caminho estrei to e sinuoso, por vezes com declives e aclives acentuados. Esta é a única via terrestre existente e utilizada pelos moradores da Prainh Branca que trabalham, estudam e fazem suas compras principalmen te na Bertioga. O acesso por mar, de um modo geral restrito ao transporte de materiais de construção e de mercadorias para os bares, fica comprometido nas ocasiōes em que o vento sudoeste atinge a praia em toda a sua extensão.

Assim como na Praia do Góis, também na Prainha Branca a po sição desempenha importante papel. Por estar situado junto à Ber tioga e à rodovia, este núcleo desfruta de uma série de vantagens en tre as quais aquelas decorrentes do afluxo de forasteiros, das possibilidades de melhores oportunidades de trabalho e de estudo part seus moradores. Todavia, esta influência do fato urbano é inferior àquela que se observa em relação à Praia do Góis, em razão da dificuldade de acesso para a Prainha Branca e, evidentemente, da desproporção existente entre Santos e Bertioga. Outro fato digno de nota é que o isolamento deste núcleo tem contribuído para torná-lo um refúgio de marginais que acampam na praia, pondo em risco a população local e afugentando visitantes.
A sobrevivência da população que, na fase contemporânea, se estabeleceu na Praia do Góis e na Prainha Branca, deu-se conforme o modelo caiçara, isto é, apoiada no extrativismo e, principalmente, na pesca.

A pesca artesanal, que tão bem marcou estes núcleos, teve duas fases, cada qual com suas peculiaridades. Na primeira, predominava a pesca em grupo que, embora coexistindo com o sistema individual, anulava-o tão logo surgissem os cardumes que motivavam e ocupavam todos os moradores sem distinção de sexo ou idade. A segunda fase foi assinalada pelo predomínio do sistema individual sobre o coletivo. Nessa fase, acentuaram-se as transformaçōes destes núcleos, uma vez que muitos dos pescadores saíram, enquanto outros passaram a desempenhar atividades estranhas à pesca.

O sistema coletivo foi praticado intensamente nos núcleos até o fim da década de 40, no Góis, e início dos anos 70, na Prainha Branca. Na Praia do Góis, em 1948, alguns pescadores, abandonando a pesca, retiraram-se e algumás das casas foram compradas por paulistanos que, por sua vez, tornaram-se assíduos freqüentadores do local, nos fins de semana. O mesmo fato se repetiu entre 1961 e 1963. Os pescadores que restaram passaram a praticar unicamente o sistema individual ou, então, adaptaram-se ao serviço de transporte em catraias, ao comércio de bebidas e petiscos no próprio local e à prestação de serviços na área urbana santista. Na Prainha Branca, já no início da década de 50, as dificuldades enfrentadas para armazenar o pescado e transportá-lo até Santos, assim como a inconstância de sua venda nas cercanias acabaram por desestimular muitos pescadores que, então, trocaram a pesca por empregos à base de salário mensal na Baixada Santista, principalmente na Bertioga. Assim mesmo, a pesca, ainda que praticada em menor escala do que no período que antecede 1940, marcou a vida do núcleo até 1974, última vez que fizeram o cerco da tainha.

Atualmente, apenas uma minoria sobrevive unicamente da pesca ainda que, nos dois núcleos, muitos a ela se dediquem, como atividade voltada para o atendimento de forasteiros ou em caráter temporário, sem dela depender para garantir a própria subsistência.

Os pescadores da Praia do Góis vendem o pescado no entreposto de pesca, no mercado de Santos, nas peixarias da Ponta da Praia ou, então, a visitantes que procuram o núcleo. $\mathrm{Na}$ "temporada" (janeiro e fevereiro), porém, o peixe é vendido no lado oposto do estuário, na Ponta da Praia, a forasteiros e a moradores da Baixada. Nos fins + de + semana de maior movimento (novembro a março), o próprio comércio local absorve quase toda a pequena produção, em 
bora alguns proprietários de bares ambém pratiquem a pesca com rede de espera. O pescado da Prainha Branca é vendido na Bertioga e em Santos ou, então, presta-se à subsistência do pescador e da sua familia.

É difícil avaliar o rendimento de um pescador artesanal, pois nem mesmo ele tem certeza do quanto recebe. Alguns garantem que “dá prá viver”, enquanto outros dizem que "a pesca es á ruim”. Pode-se afirmar, todavia, que eles ganham mais quando aumenta o movimento de turistas na Baixada, pois a pesca nāo é mais feita segundo a presença e a profusão de indivíduos de uma determinada espécie, mas sim, de acordo com as possibilidades de venda do produto aos visitan es que procuram a região.

No entanio, os pescadores da Praia do Góis e da Prainha Branca concordam, unanimemente, que o peixe diminuiu. Entre as razões para justificar esse fato apon am as grandes firmas dotadas de equipamentos modernos que vasculham os mares e a poluição ambiental causada pelas embarcações que lançam resíduos, espe ialmente óleo, que com a maré baixa permanece à superfície. Além disso, os pescadores da Praia do Góis atribuem a redução de peixes à poluição sonora causada pelo ruído de barcos e pessoas.

Mui as mudanças, entretanto, ocorreram na Praia do Góis, embora a pesca siga os processos e técnicas tradicionais. Assim, atualmente, é possível distinguir, nesse núcleo, três categorias de pescadores artesanais:

a) aqueles que têm a pesca como único meio de subsistência, constituindo uma pequena minoria $(6,5 \%$ da força de trabalho);

b) os que se dedicam ao que chamam de "pesca turística" como complemento do serviço de catraias $(9,7 \%$ da força de trabalho);

c) outros, cujo número é difícil de avaliar, que desempenham funções variadas e, eventualmente, pescam; incluem-se, aqui, alguns empregados e proprietários de bares locais que pescam para vender o pescado no próprio estabelecimento, já preparado sob a forma de refeições e petiscos.

A chamada "pesca turística" constitui uma modalidade de lazer para o visitante, que contrata, por um determinado tempo, os serviços de um catraieiro com a finalidade de realizar passeios e, mais freqüentemente, pescarias. Esse fato, por si só, não bastaria para definir o catraieiro que se dedica à "pesca turística" como um pescador. Todavia, as entrevistas realizadas revelaram que este elemento 6 um conhecedor do ofício e, além disso, que a maioria sempre teve na 72 pesca seu principal meio de subsistência. Todas estas considerações permitem afirmar que a "pesca turística" é uma forma particular de adaptação do pescador à condição de periferia urbana que este núcleo passou a ocupar na Baixada Santista, porque o elemento que a ela se dedica, embora adaptado às novas circunstâncias do desenvolvimento de Santos, de onde extravasa a população que procura seus serviços, ainda vive ligado ao mar e à pesca.

De um modo geral, a procura por passeios e pela "pesca turística" aumenta a partir de setembro, alcança o auge entre novembro e março (o período mais quente do ano), declina a partir de abril até atingir o mínimo em julho (o mês mais frio). É interessante observar que embora os meses frios, que correspondem ao deslocamento de cardumes para o norte, sejam propícios à pescaria, aqueles que se dedicam à "pesca turística" apontam os meses mais quentes como mais compensadores. Isto ocorre porque o afluxo de visitantes nessa época do ano representa colocação certa do pescado, o que contribui para estimular não só esta categoria de pescadores, mas também todos os demais que se dedicam à atividade pesqueira em geral. Assim sendo, percebe-se que a chamada "pesca turística" contribui de maneira efetiva para o sustento de um razoável número de habitantes da Praia do Góis.

O sistema de catraias como transporte coletivo na Praia do Góis também estruturou-se quando se acentuou a dependência do núcleo em relação a Santos e quando o número de visitantes aumentou. $\mathrm{O}$ transporte em catraias ocupa $40,3 \%$ da força de trabalho, sendo que desta, 9,7\% acumulam esta função com a da "pesca turística". Nos fins de semana, quando o núcleo se anima com a chegada dos visitantes, as catraias lotadas cruzam o estuário a cada 15 minutos. Nestas ocasiōes, o lucro dos catraieiros aumenta consideravelmente e, segundo alguns, é este movimento temporário a única razāo do elevado número de pessoas que dependem dessa atividade para viver.

Os "bares" constituem a única forma de comércio existente nos dois núcleos, exceção feita a uma pequena mercearia que vende gêneros de primeira necessidade aos moradores da Prainha Branca, mas somente quando não existe possibilidade de realizar estas compras na Bertioga. Todavia, os "bares", que de modo geral vendem bebidas, petiscos e até mesmo refeições, estão inteiramente voltados para $o$ atendimento de visitantes.

Estes "bares" revelam, na modéstia de seu aspecto, a precariedade do comércio local e em nada se assemelham aos estabelecimen tos congêneres das áreas urbanizadas próximas. Na Praia do Góis, entretanto, embora construídos de madeira e muito rústicos, os bares 
apresentam um aspecîo mais cuidado, além de contarem com alguns equipamentos como cadeiras, mesas, aparelhos de som e geladeiras, que revelam uma certa prosperidade em virtude do maior movimento quando comparados aos da Prainha Branca.

Vazios, e muitas vezes fechados, de segunda a sexta-feira, os bares da Praia do Góis e da Prainha Branca, porém, ficam repletos nos feriados e fins de semana, principalmente nos meses de verão (dezembro a março), quando se transformam num ponto de parada obrigatória para os que buscam estes núcleos como opção de lazer. Muitos daqueles que procuram a Praia do Góis provêm da capital, de Atibaia (São Paulo) e mesmo de Santos, enquanto que na Prainha Branca a maioria dos forasteiros procede da cidade de São Paulo e da prōpria região. Os "bares" existentes nesses núcleos foram instalados a partir de 1970, justamente quando aumentou o movimento de visitantes. Atualmente, $10,9 \%$ da população ativa da Praia do Góis e 19,3\% daquela da Prainha Branca dependem dessa atividade para viver.

Deve-se mencionar que, a partir de 1970, o campismo começou a ser praticado na Prainha Branca, muito embora proibido pela Prefeitura do Município do Guarujá, e vem contribuindo para aumentar o movimento dos "bares". Os campistas são geralmente simpáticos aos moradores, uma vez que representam consumo e, portanto, renda para os modestos comerciantes locais. Muitos campistas passaram mesmo a alugar quartos em residências vagas para permanecer por tempo mais longo no núcleo $\mathrm{e}$, assim, originaram nova fonte de rendimento para os moradores locais. Contudo, o isolamento da Prainha Branca, em razão das dificuldades de acesso, bem como a proximidade de áreas sub-urbanizadas, concorreram para que, a partir de 1976, esse núcleo fosse procurado por marginais que nele acampam quase permanentemente. Segundo os moradores, eles são uma subespécie de campistas: os "barraqueiros". Este fato vem afugentando os visitantes e colocando em risco a segurança da comunidade que nāo tem condiçōes para defender-se sozinha e nem conta com a ajudâ das autoridades competentes. Assim, Prainha Branca, antes um recanto tranqüilo, procurado em virtude da posiçāo que ocupa na Baixada Santista, das características que possui e que foram preservadas pelo isolamento, passou a ser um local evitado pelos visitantes, justamente em decorrência daqueles mesmos fatores que constituíam as razōes de seu atracivo.

Além de um pequeno estaleiro existente na Praia do Góis que fabrica e repara embarcaçōes, as demais atividades encontradas nos dois núcleos estão relacionadas à prestação de serviços em áreas ur. 74 banas. Assim, 30,6\% da população ativa da Praia do Góis desempenham, em Santos, funçōes públicas ou trabalham como auxiliares de escritório, técnicos de rádio, comerciários, bancários e manicures. Todavia, na Prainha Branca, nãosó a proporção daqueles que prestam serviços na área urbana é maior $(81,5 \%)$ como também as funçōes são mais modestas: funcionários encarregados de limpeza em repartições públicas, caseiros, embaladores em indústrias de processamento de pescado, pedreiros, motoristas, lavadeiras e domésticas. Percebe-se, assim, que a proximidade de Bertioga atraiu os moradores da Prainha Branca para a prestação de serviços na área urbana, enquanto que na Praia do Góis o resultado foi inverso, pois a presença de Santos contribuiu para aumentar o número de visitantes, criar empregos no próprio núcleo e, conseqüentemente, fixar a população local. Assim, na Praia do Góis, $61,2 \%$ da populaçao ativa dependem do afluxo de forasteiros para sobreviver.

Foi a partir dessas transformações, iniciadas nos dois núcleos desde 1940 e acentuadas na década seguinte, que as atividades modernas, menos cansativas e incertas do que a pesca e a roça, e também mais compensadoras, passaram a ser motivo de atração para seus habitantes. Por isso, atualmente, na Praia do Góis e na Prainha Branca, observa-se uma justaposição das atividades modemas aos meios tradicionais de subsistência, o que significa, em outras palavras, que o caiçara, para sobreviver, procurou tirar proveito dos efeitos da urbanização.

\section{CONSIDERAÇÕES FINAIS}

Finalmente, resta acrescentar que não apenas as questōes ambientais mas, também, aquelas particularizadas, como é o caso das comunidades de pescadores artesanais, constituem assuntos relevantes nas repercussôes que o turismo pode provocar no espaço geográfico. Por isso mesmo, estas questôes, muito embora não sejam as únicas, devem ser consideradas e colocadas acima de qualquer interesse, mesmo daqueles de natureza política e econômica. Esta te $\mathrm{m}$ sido a mensagem de muitos especialistas que condenam o turismo dirigido unicamente pelo interesse econômico e sugerem, como alternativa, a prática do turismo cultural, apoiado no conhecimento do meio-ambiente em seu sentido pleno, o que inclui o povo com todas as suas tradiçôes. 


\section{NOTAS BIBLIOGRÁFICAS}

I. Sobre aspectos conceituais do turismo, consultar: ACERENZA, M.A. Administración del turismo. México : Trillas, 1985. cap.I

2. A propósito das definiçōes de meio-ambiente, consultar: GEORGE, Pierre. L'environnement. Paris : PUF, 1973. p. 5-20. (Coleçāo "Que sais-je", 1450)

3. LERNER, S.C. Social impact assesment: some hard questions and basic techniques Ontario : University of Waterloo (unpublished workshop paper). Apud: MATHIESON, A.\& WALL, G. Tourism: economic, physical and social impacts. London : Longman, 1982, p. 93.

4. MATHIESON, A.\& WALL, G. Obra citada, 208p.

5. MICHAUD, J. Le tourisme face à lenvironnement. Paris : PUF, 1983, 234 p.

6. MATHIESON, A. \& WALL, G. Obra citada, p.94.

7.É o caso de alguns artigos publicados nos Anais do Simpósio sobre "A comunidade ve. getal como unidade biológica, turística e económica", publicaçáo ACIESP n. 15 , Secretaria da Cultura, Ciência e Tecnologia, Academia de Ciências do Estado de Sāo Paulo, 1978, p. 207 e segs.

8. Conforme análise feita por MATHIESON, A.\& WALL, G. Obra citada, p. 93-132.

9. Idem, p. 105-12.

10. Idem, p. 121.

11. PEARCE, D. Tourism development. London : Longman, 1981, p.6-10.

12.MATHIESON, A. \& WALL, G. Obra citada, p. 116.

13. MIOSSEC, J. Elements pour une theorie de l'espace touristique. Les Cahiers du Tourisme. C-36, Aix-en-Provence, 1976

14. MATHIESON, A.\& WALL, G. Obra citada, p. 121.

15. MICHAUD, J. Obra citada, p. 93-117.

16. Idem, p. 95.

17. A proposito das repercussóes do turismo em áreas litorâneas, consultar: BARBAZA Y. Trois types d'intervention du tourisme dans l'organisation de I'espace littoral. Annales de Géographie. n. 434, p. 446-69, 1970.

18. Sobre impactos litorâneos e equipamentos de apoio, ver: NOVO, F. G. Effectos ecologicos del equipamiento turistico. Estudios Territoriales, n. 5, enero-marzo, 1982, p. 137-44.

19. MATHIESON, A. \& WALLL, G. Obra citada, p. 115.

20. KARAN, P.P. \& MATHER, C. Tourism and environment in the Mount Everest Region. The Geographical Review. v. 75, n. 1, 1985, p. 93-5.

21. A respeito do aspecto autodestrutivo do turismo é interessante o trabalho de: TYLER, C. Killing the goose. Geographical. Oct., 1989, p. 18-21.

22. Com referência aos impactos socioculturais do desenvolvimento turístico, consultar: PEARCE, D. Obra citada, p. 50-3.
23. MATHIESON, A.\& WALL, G. Obra citada, p. 127.

24. TYLER, C. (obra citada) apresenta uma "Seleçāo de histórias bem sucedidas", onde mostra as possibilidades de convivência benéfica com o turismo.

25. MATHIESON, A.\& WALL, G. Obra citada, p. 98.

26. Idem, p. 98-9.

27. TULIK, O. Praia do Gois e Prainha Branca: núcleos de periferia urbana na Baixada Santista. Sāo Paulo : FFLCH-USP, 1979, 284 p. (Dissertaçāo de Mestrado)

28. TULIK, O. Praia do Góis e Prainha Branca: núcleos de periferia urbana na Baixada Santista. Coleção Museu Paulista, v. 1, 1981, p. 137-59. 